\title{
Severity of Curvularia Stem Blight Disease of Cassava in West Africa
}

\author{
W. Msikita, Pennsylvania Department of Agriculture, 2301 N. Cameron Street, Harrisburg PA 17110; and \\ H. Baimey and B. D. James, International Institute of Tropical Agriculture, Biocontrol Center for Africa, 08 BP \\ 0932, Tri Postal, Cotonou, Benin, West Africa
}

\begin{abstract}
Msikita, W., Baimey, H., and James, B. D. 2007. Severity of Curvularia stem blight disease of cassava in West Africa. Plant Dis. 91:1430-1435.

In diagnostic surveys, Curvularia stem blight affected 9,13 , and $38 \%$ of cassava fields, respectively, in Benin, Ghana, and Nigeria. Disease incidence (number of plants with visible symptoms per total sampled) ranged between 0 and $80 \%$, and severity (number of lesions) between 2 and 25 lesions per stem. In greenhouse studies, the fungus inhibited shoot growth depending on the degree of bud colonization, such that when buds were completely colonized, they failed to sprout. Partially colonized buds sprouted, but depending on genotype, overall growth was reduced 20 to $50 \%$ compared with healthy stems. Shoot growth for all artificially inoculated cultivars was consistently lower than for the respective noninoculated plants, and they suffered up to 50\% leaf abscission. In two field localities, shoot sprouting for cultivars TMS 30572 and Odongbo was reduced 4 to $18 \%$ and 26 to $58 \%$ compared with noninoculated stems.
\end{abstract}

Additional keywords: emerging disease, human pathogen, leaf production

The importance of cassava as a major food crop for Africa, Asia, and Latin America has been enumerated many times $(7,11)$. Cassava field production is hampered by biotic and abiotic constraints. Among the biotic constraints, pests and diseases cause significant yield reduction. For instance, Lozano and Terry (15) estimated that a total of 30 different viral, fungal, and bacterial diseases alone or in combination reduce yield by up to $90 \%$. In addition to the familiar diseases such as the cassava mosaic disease and bacterial blights, a number of pathogens have been identified in the last 10 years, including Macrophomina phaseolina (Tass) Goidanich (21), Nattrassia mangiferae (Syd. P. Syd.) B. Sutton \& Dyko (19,24), Fusarium moniliforme J. Sheld. (22), and the Curvularia stem blight pathogen (Curvularia lunata (Wakker) Boedijn) (23).

The impact of these emerging diseases on cassava production largely remains poorly understood. In addition, the discovery of $C$. lunata as a pathogen of cassava raised new concerns because the fungus is a cosmopolitan soil inhabitant and has been documented as pathogenic on humans (4). In the last 20 years, there have been increased reports of $C$. lunata infection of both immunocompromised and immunocompetent humans $(5,27,28)$ that

Corresponding author: W. Msikita

E-mail: wmsikita@state.pa.us

Accepted for publication 11 June 2007.

doi:10.1094/PDIS-91-11-1430

(C) 2007 The American Phytopathological Society resulted in severe respiratory tract, cutaneous, central nervous system $(8,14)$, and corneal impairments $(5,10,16,18,32)$. However, there is a lack of information associating cassava culture and human infection caused by $C$. lunata, although a relationship between human infection and other crops has been noted $(32,33)$. Further, increased incidences of $C$. lunata infection in humans have been associated with the hot, humid conditions (6) that are typical of tropical environments. All of these predisposing conditions are favorably met in West Africa. Further, cassava is a major food crop widely grown in West Africa, and the prevailing warm, humid conditions of the region are very conducive for $C$. lunata proliferation.

In observation studies in the greenhouse, we noted that $C$. lunata adversely affected stem sprouting, elongation, and leaf retention ability of certain cultivars. These observations prompted us to conduct intensive diagnostic studies of selected cassava producing areas in Benin, Ghana, and Nigeria of the West African subregion, followed by greenhouse studies to gain a better understanding of the impact of the disease on cassava, and to increase awareness of the potential health-related problems associated with the causal organism.

\section{MATERIALS AND METHODS}

Field assessment. Curvularia stem blight was discovered on cassava at Bonsu $\left(6^{\circ} 17^{\prime} \mathrm{N}, 0^{\circ} 27^{\prime} \mathrm{W}\right)$ in the south part of Ghana in 1995 (20). Between 1996 and 1997, we conducted intensive disease surveys in Benin, Ghana, and Nigeria in the dry seasons (November to December) to cover areas similar in latitude to Bonsu.
Only dry-season surveys were conducted because of the difficulties in accessing some of the localities during the rainy season. In all three countries, fields were selected based on age of the crop. Only plants $\geq 9$ months old were surveyed because the disease is readily visible on cassava stems of this age. In Benin, 66 fields were randomly selected between lat. $6^{\circ} 25^{\prime} \mathrm{N}$ and $11^{\circ} 25^{\prime} \mathrm{N}$. In Ghana, 60 fields between lat. $4^{\circ} 55^{\prime} \mathrm{N}$ and $8^{\circ} 16^{\prime} \mathrm{N}$, and in Nigeria, 47 fields between lat. $4^{\circ} 50^{\prime} \mathrm{N}$ and $7^{\circ} 56^{\prime} \mathrm{N}$, were selected. In each field, 30 plants were randomly selected in a diagonal across the field. Plants in the diagonal were visually examined from top to bottom for symptoms of Curvularia. Disease incidence (percentage of diseased plants per total number sampled) and severity (number of lesions per stem) were recorded for each field.

Cassava germplasm collections in Benin (located at Niaoli: $6^{\circ} 40^{\prime} \mathrm{N}, 2^{\circ} 7^{\prime} \mathrm{E}$ ) and Ghana (located at Bonsu: $6^{\circ} 17^{\prime} \mathrm{N}, 0^{\circ} 27^{\prime} \mathrm{E}$ ) were also assessed for incidence (percentage of total number of plants infected per total number of plants in an experimental plot) and disease severity (number of lesions per stem). In both locations, the germplasm was planted in $2 \times 6 \mathrm{~m}$ long rows spaced $1 \mathrm{~m}$ apart, and the plants were 9 and 10 months, respectively, at the time of assessment. All statistical analyses were performed using SAS version 8.2 (SAS Institute Inc., Cary, NC). Means of disease incidence and severity were calculated and compared using the least significant differences (LSD) method at 95\% confidence interval.

Greenhouse studies. Thirty centimeter long, naturally infected cassava stems (three to five lesions) for each of the cultivars 'Amazon', 'Axotonon', 'Odongbo', and TM 30572 were collected from 9month-old field grown plants, and replanted in sterilized sand (autoclaved for 1 $\mathrm{h}$ at $1.06 \mathrm{~kg} \cdot \mathrm{cm}^{-1}$ pressure). Following planting, shoot length $(\mathrm{cm})$ was recorded weekly for 4 weeks. Treatments comprised stem cuttings partially or completely colonized (naturally covered by fungal stroma), or noncolonized (control) by $C$. lunata. Control stems for each of the four cultivars were disinfested in hot water $\left(52^{\circ} \mathrm{C}, 5\right.$ min). After planting, stems were maintained (at 28 to $30^{\circ} \mathrm{C}$ ) in a greenhouse under natural light (12 h day length) and watered two times per week. The experiment was repeated three times (each time using freshly collected stems) in a com- 
pletely randomized design with five replications per treatment. Mean shoot growth per treatment per week was calculated and compared by the LSD method of SAS.

Field growth of infected and noninfected stems was studied at two sites in Nigeria: Amusho and Kotopo $\left(7^{\circ} 10^{\prime} \mathrm{N}, 3^{\circ} 25^{\prime} \mathrm{E}\right)$, located 20 miles apart, and selected because of high disease incidence recorded during surveys and similarity in temperature, rainfall, and humidity. Due to a limited supply of infected stems, and quarantine restrictions in moving infected stems, only cultivars 'Odongbo' and 'TMS 30572' that are widely grown in Nigeria were used in the field assessment. Stems of the two cultivars (approximately $30 \mathrm{~cm}$ long) were planted in

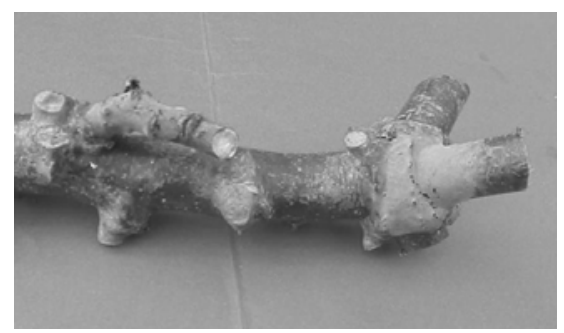

Fig. 1. Curvularia lunata colonization of nodes on a woody stem of cassava. two rows $(1 \times 1 \mathrm{~m}$ within and between $)$ in 6 $\mathrm{m}^{2}$ plots, arranged in a completely randomized design with five replications for each cultivar. Means of shoot length were separated and compared by the LSD method.

To inoculate stems, C. lunata (isolate 11 , collected from infected cassava stems at Bunso) was cultured on potato dextrose agar (PDA) acidified to $\mathrm{pH} 4.5$ with 4 $\mathrm{ml} /$ liter lactic acid, and frozen at $-80^{\circ} \mathrm{C}$ for 3 months. A week before the experiment was initiated, the fungus was subcultured on acidified PDA and incubated at $25^{\circ} \mathrm{C}$ for 10 days under cool-white fluorescent light at $30 \mathrm{~mol} \cdot \mathrm{m}^{-2} \cdot \mathrm{s}^{-1}$ and a 12 -h photoperiod. These cultures were used to inoculate stems for cassava cultivars. Inoculum was prepared from a 5-mm-diameter PDA mycelial plug cut out of the edge of the petri plate with a number 2 cork borer. Conidia were washed, added to $2 \mathrm{ml}$ of sterilized distilled water, and adjusted to $10 \times 10^{3}$ $\mathrm{ml}^{-1}$. Stems used for the experiment were obtained from the southern part of Benin, which was known to be free of the disease based on our initial survey. Five stems, approximately $30 \mathrm{~cm}$ long, of each of the four cultivars were disinfested in hot water $\left(52^{\circ} \mathrm{C}, 5 \mathrm{~min}\right)$ and wound-inoculated (sliced with a scalpel) just above the

Table 1. Field incidence and severity of Curvularia stem blight of cassava in three countries of West Africa

\begin{tabular}{|c|c|c|c|c|}
\hline Country and site & Latitude ${ }^{\circ} \mathbf{N}$ & Longitude ${ }^{\circ} \mathbf{E}$ & Incidence $(\%)^{\mathrm{y}}$ & Severity $^{\mathrm{z}}$ \\
\hline \multicolumn{5}{|l|}{ Benin } \\
\hline Dagadoxo 1 & $7^{\circ} 53^{\prime}$ & $1^{\circ} 56^{\prime}$ & 26.2 & 0.8 \\
\hline Dagadoxo 2 & $7^{\circ} 54^{\prime}$ & $1^{\circ} 55^{\prime}$ & 55.6 & 10.5 \\
\hline Monkpa & $7^{\circ} 55^{\prime}$ & $2^{\circ} 02^{\prime}$ & 48.7 & 1.1 \\
\hline Agoua & $8^{\circ} 11^{\prime}$ & $1^{\circ} 58^{\prime}$ & 23.3 & 0.5 \\
\hline Banté 1 & $8^{\circ} 23^{\prime}$ & $1^{\circ} 53^{\prime}$ & 20.0 & 0.6 \\
\hline Banté 2 & $8^{\circ} 23^{\prime}$ & $1^{\circ} 54^{\prime}$ & 23.3 & 0.2 \\
\hline \multicolumn{5}{|l|}{ Ghana } \\
\hline Bekwai & $6^{\circ} 12^{\prime}$ & $2^{\circ} 18^{\prime}$ & 10.2 & 3.8 \\
\hline Awaso & $6^{\circ} 13^{\prime}$ & $2^{\circ} 16^{\prime}$ & 14.7 & 7.6 \\
\hline Atkrom & $6^{\circ} 15^{\prime}$ & $0^{\circ} 26^{\prime}$ & 67.4 & 5.4 \\
\hline Sefwu Wiaso & $6^{\circ} 15^{\prime}$ & $2^{\circ} 29^{\prime}$ & 12.2 & 2.4 \\
\hline Bunso & $6^{\circ} 17^{\prime}$ & $0^{\circ} 27^{\prime}$ & 74.4 & 7.2 \\
\hline Osino & $6^{\circ} 21^{\prime}$ & $0^{\circ} 29^{\prime}$ & 87.1 & 21.7 \\
\hline Ankase & $6^{\circ} 26^{\prime}$ & $0^{\circ} 36^{\prime}$ & 80.6 & 20.2 \\
\hline Nkokow & $6^{\circ} 31^{\prime}$ & $0^{\circ} 44^{\prime}$ & 6.2 & 2.0 \\
\hline \multicolumn{5}{|l|}{ Nigeria } \\
\hline Akwa Ibom & $5^{\circ} 07^{\prime}$ & $7^{\circ} 30^{\prime}$ & 30.0 & 10.1 \\
\hline Isiokpo & $5^{\circ} 30^{\prime}$ & $6^{\circ} 15^{\prime}$ & 16.7 & 1.2 \\
\hline Obong Itam & $5^{\circ} 30^{\prime}$ & $7^{\circ} 20^{\prime}$ & 36.7 & 3.3 \\
\hline Akamkpa & $5^{\circ} 39^{\prime}$ & $7^{\circ} 50^{\prime}$ & 36.7 & 3.2 \\
\hline Umuagwo & $5^{\circ} 40^{\prime}$ & $6^{\circ} 30^{\prime}$ & 3.3 & 1.0 \\
\hline Ikot Ekpene & $5^{\circ} 40^{\prime}$ & $7^{\circ} 10^{\prime}$ & 20.0 & 5.5 \\
\hline Oforolla & $5^{\circ} 50^{\prime}$ & $6^{\circ} 20^{\prime}$ & 61.3 & 2.2 \\
\hline Ikot Ekpo & $5^{\circ} 52^{\prime}$ & $7^{\circ} 10^{\prime}$ & 33.3 & 1.4 \\
\hline Alagunfan & $6^{\circ} 36^{\prime}$ & $4^{\circ} 36^{\prime}$ & 46.7 & 2.4 \\
\hline Imaka & $6^{\circ} 44^{\prime}$ & $3^{\circ} 56^{\prime}$ & 33.4 & 3.7 \\
\hline Itori & $6^{\circ} 54^{\prime}$ & $3^{\circ} 15^{\prime}$ & 10.0 & 3.7 \\
\hline Owojo & $7^{\circ} 06^{\prime}$ & $3^{\circ} 40^{\prime}$ & 56.7 & 20.5 \\
\hline Kotokpo & $7^{\circ} 10^{\prime}$ & $3^{\circ} 25^{\prime}$ & 93.3 & 16.9 \\
\hline Fiditi & $7^{\circ} 14^{\prime}$ & $3^{\circ} 54^{\prime}$ & 60.00 & 18.1 \\
\hline Okerebemtre & $7^{\circ} 20^{\prime}$ & $4^{\circ} 35^{\prime}$ & 73.3 & 2.5 \\
\hline Ayiribi & $7^{\circ} 27^{\prime}$ & $3^{\circ} 51^{\prime}$ & 46.7 & 13.1 \\
\hline Adana & $7^{\circ} 40^{\prime}$ & $4^{\circ} 05^{\prime}$ & 86.7 & 12.0 \\
\hline Larowoyan & $7^{\circ} 49^{\prime}$ & $4^{\circ} 23^{\prime}$ & 53.3 & 11.0 \\
\hline $\mathrm{LSD}_{005}$ & & & 14.2 & 2.4 \\
\hline
\end{tabular}

\footnotetext{
${ }^{\text {y }}$ Percentage of plants symptomatic for Curvularia stem blight.
}

${ }^{\mathrm{z}}$ Mean number of lesions per stem $(N=30)$. nodes. One milliliter of mycelial and conidial suspension was then applied to each wound. The stems were kept in a plastic bag for $24 \mathrm{~h}$ before planting into autoclaved sterilized sand (moist), and after planting were maintained in the greenhouse at 28 to $30^{\circ} \mathrm{C}, \geq 90 \%$ relative humidity, and natural light. All plants were watered two times per week. Control plants were similarly wounded but treated with sterilized distilled water. The experiment was arranged in a completely randomized design with five replications for each of the control and inoculated stems. Shoot length was recorded weekly, and means of shoot lengths were separated and compared as described above.

To produce leaves for inoculation, stems from each of the four cultivars mentioned above were sown and maintained in the greenhouse as described above. Four weeks after sowing, the two lower most leaves on the stem were wounded using four pins affixed to a cork, and $1 \mathrm{ml}$ of mycelial conidial suspension of $C$. lunata (adjusted to $10 \times 10^{3}$ conidia) was applied to the wounds. Control plants were similarly wounded but treated with sterilized distilled water. All plants were maintained in the greenhouse at $\geq 90 \%$ relative humidity under natural light at 28 to $30^{\circ} \mathrm{C}$ and were watered twice weekly. There were five replications for each treatment arranged in a completely randomized design. At the end of 5 weeks, the number of abscised leaves was counted for each plant.

\section{RESULTS}

Field surveys. On naturally infected plants, C. lunata appeared as grayish brown mycelial mats (stroma) predominantly on the woody stem portion (Fig. 1).

Table 2. Disease incidence and severity of Curvularia stem blight of the cassava germplasm collection in Ghana

\begin{tabular}{lcc}
\hline Accession no. & $\begin{array}{c}\text { Incidence } \\
(\boldsymbol{\%})^{\mathbf{y}}\end{array}$ & Severity $^{\mathbf{z}}$ \\
\hline JK 001 & 25.0 & 1.0 \\
JK 005 & 40.0 & 2.2 \\
JK 006 & 80.0 & 8.0 \\
JK 009 & 50.0 & 18.4 \\
JK 016 & 27.3 & 5.0 \\
JK 021 & 55.6 & 5.0 \\
JK 022 & 20.0 & 15.5 \\
JK 026 & 77.8 & 3.0 \\
KAA 90/050 & 57.1 & 7.5 \\
KAA 90/053 & 28.6 & 4.0 \\
KAA 90/054 & 20.0 & 1.0 \\
KAA 90/056 & 57.1 & 3.0 \\
KAA 90/058 & 33.3 & 6.0 \\
KAA 90/065 & 50.0 & 7.0 \\
KAE 90046 & 25.0 & 7.5 \\
MC 90/011 & 16.7 & 8.0 \\
MC 90/013 & 30.0 & 10.0 \\
MC 90/020 & 20.0 & 25.0 \\
MC 90/033 & 20.0 & 2.0 \\
LSD 0.05 & 10.1 & 3.4 \\
\hline
\end{tabular}

y Percentage of plants in a plot symptomatic for Curvularia stem blight.

${ }^{\mathrm{z}}$ Mean number of lesions per stem $(N=12)$. 
The mats were generally confined to the nodes. Under severe infection, the stroma occasionally spread to nodes on the green portion of the stems, but not the shoot tip. At $\times 200$ magnification, mycelia and conidia typical for Curvularia were observed (31). The identity of the fungus was confirmed by the Commonwealth Mycological Institute in our earlier study (23).

Of the 66 fields surveyed in Benin, $C$. lunata appeared confined to two localities (involving six fields, and representing 9\% of total fields surveyed) around (latitude, longitude) $7^{\circ} 53^{\prime} \mathrm{N}, 1^{\circ} 56^{\prime} \mathrm{E}$ to $7^{\circ} 55^{\prime} \mathrm{N}$, $2^{\circ} 02^{\prime} \mathrm{E}$ to $8^{\circ} 11^{\prime} \mathrm{N}, 1^{\circ} 58^{\prime} \mathrm{E}$ and $8^{\circ} 23^{\prime} \mathrm{N}$, $1^{\circ} 54^{\prime} \mathrm{E}$ (Savalou and Banté area). Similarly, of the 60 fields surveyed in Ghana, the disease was found in eight fields $(13 \%$ of total fields surveyed) and appeared confined to the vicinity of Bonsu and Kumasi (i.e., from $6^{\circ} 12^{\prime} \mathrm{N}, 2^{\circ} 18^{\prime} \mathrm{E}$ to $6^{\circ} 31^{\prime} \mathrm{N}$, $\left.0^{\circ} 44^{\prime} \mathrm{E}\right)$. However, in southwestern Nigeria, the disease appeared more widespread. Forty-seven fields were surveyed in Nigeria, and the disease appeared in 18 fields or $38 \%$ of total fields surveyed (Table 1). Disease incidence and severity varied significantly in all three countries. The highest mean incidence (93\%) was recorded at Kotopo $\left(7^{\circ} 10^{\prime} \mathrm{N}, 3^{\circ} 25^{\prime} \mathrm{E}\right)$, while the highest mean severity (21 lesions per plant) was recorded at Osino $\left(6^{\circ} 21^{\prime} \mathrm{N}, 0^{\circ} 29^{\prime} \mathrm{E}\right)$ in Ghana. The lowest field incidence (3\%) was recorded in Nigeria, while the lowest mean severity (a single lesion per plant) was recorded in Benin. Overall disease severity was lowest in Benin (Table 1) compared with the other two countries.

Disease spread in the germplasm collection in both Benin and Ghana was dependent on natural inoculum and prevailing weather conditions. No Curvularia stem blight was observed in the cassava germplasm collection in Benin. However, in the Ghana germplasm collection (comprising 118 accessions), 19 accessions (16\%) were infected by $C$. lunata. Among these, incidence and severity of the disease varied significantly. Incidence of infected plants per plot ranged between $17 \%$ in ' $\mathrm{MC}$ 90/010' to $80 \%$ in 'JK 006'. Mean disease severity ranged from one lesion per stem ('JK 001' and 'KAA 90/54') to 25 lesions per plant for 'MC 90/020' (Table 2).

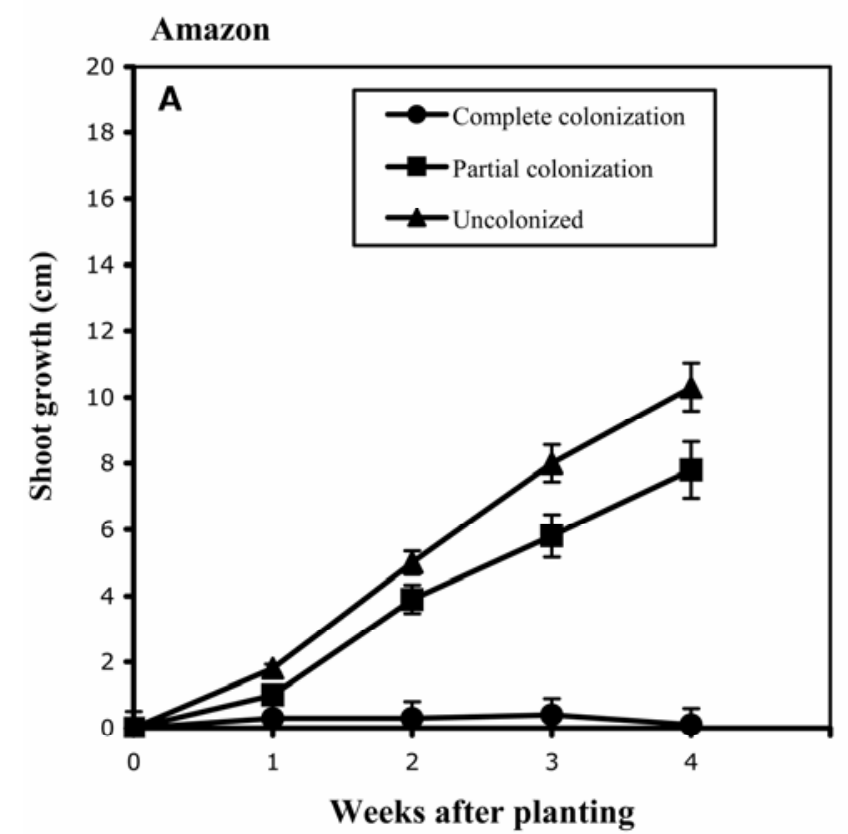

Odongbo

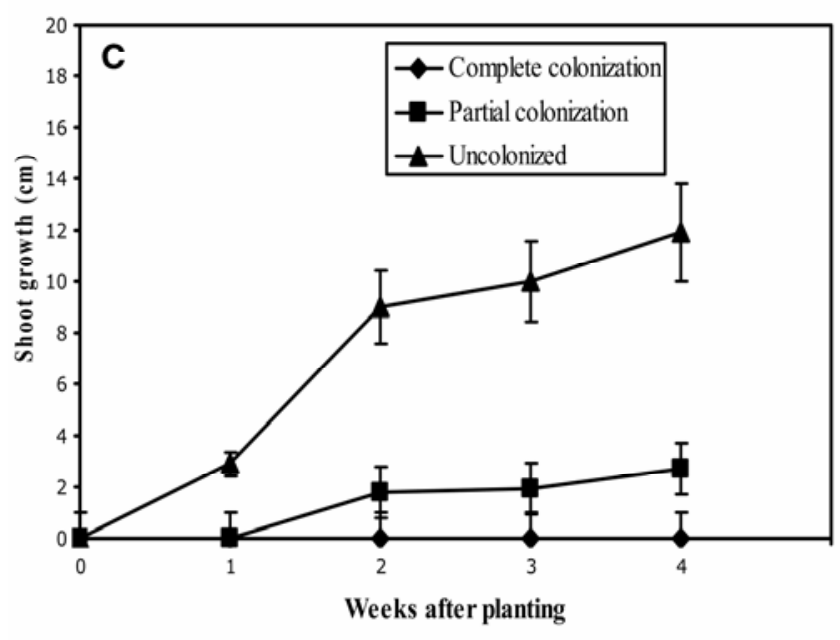

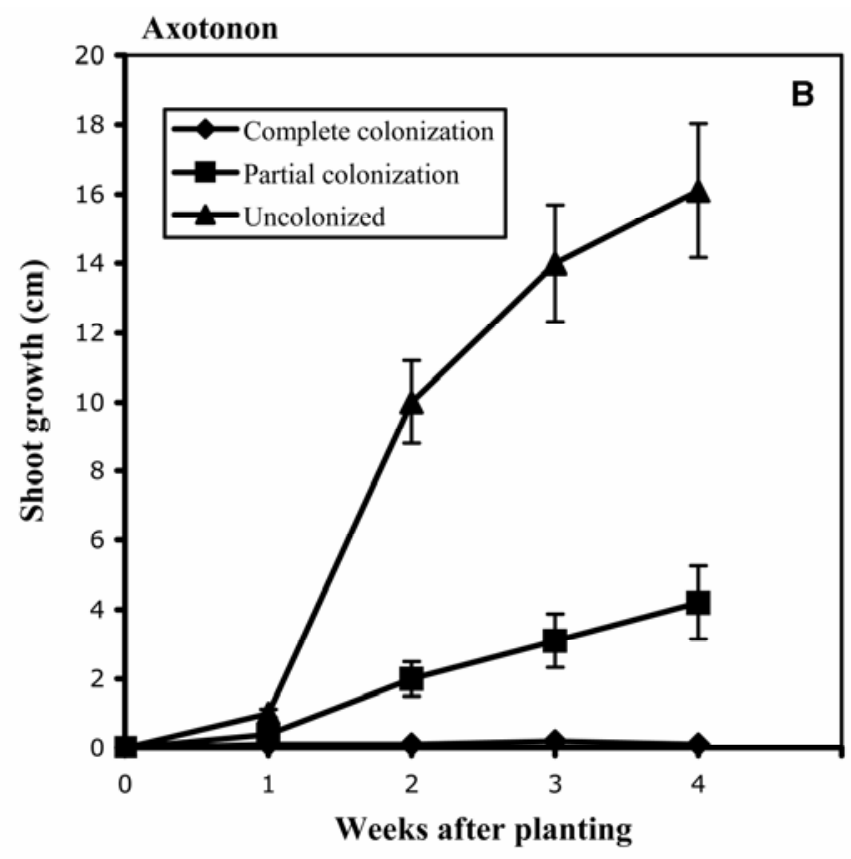

TMS 30572

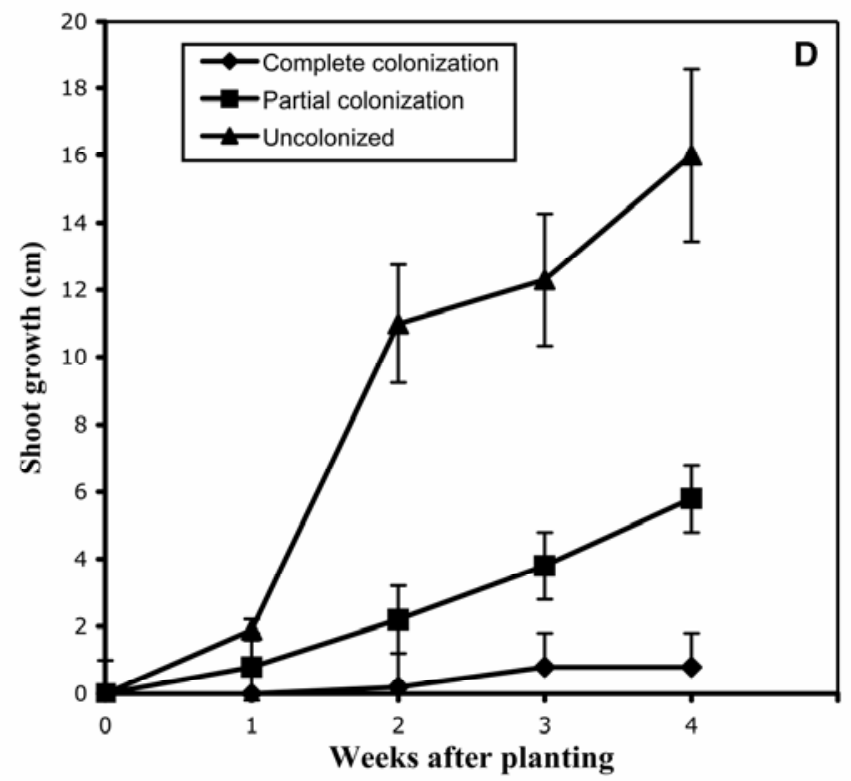

Fig. 2. Greenhouse growth of four cassava cultivars: A, Amazon, B, Axotonon, C, Odongbo, and D, TMS 30572, infected with Curvularia lunata. Standard deviation values are shown as error bars. 
Field incidence and severity data for leaf infection was difficult to assess accurately because symptoms produced by Curvularia blight (blighted patches surrounded by a spreading yellow area) were indistinguishable from those produced by Cercospora blight (Cercospora viscosae Muller \& Chupp).

Greenhouse studies. Buds on naturally infected stems sprouted within 1 week after planting. In all five cultivars evaluated, uninfected buds grew into 6- to 10cm-long shoots within 2 weeks after planting. For all cultivars, partially colonized buds sprouted, but shoot growth was significantly reduced by 20 to $50 \%$ (depending on the genotype) compared with healthy stems (Fig. 2). When $C$. lunata completely colonized the buds, very little growth (e.g., <2 cm in 'TMS 30572' and 'Amazon') or no growth ('Axotonon' and 'Odongbo') was recorded 4 weeks after planting. In the field, shoot sprouting was significantly lower (higher shoot sprouting failure) for infected stems for both 'Odongbo' and 'TMS 30572' relative to their respective noninoculated plants. On 'TMS 30572', only 4 to $5 \%$ of shoots germinated compared with 6 to $30 \%$ for noninfected stems. On 'Odongbo', shoot sprouting ranged between 0 and $4 \%$ and 12 and $62 \%$, respectively, for infected and noninfected stems. There also were significant differences between percentages of shoot sprouting between the two localities. Overall sprouting for 'Odongbo' was significantly lower than that for 'TMS 30572' (Fig. 3).

Shoots sprouted in both inoculated and noninoculated stems for all four cultivars 1 week after planting, but growth was significantly reduced (Fig. 4). Within 2 days of inoculation, a lesion developed around the inoculation site. Two weeks after inoculation, diseased leaves turned yellow and abscised. On diseased plants, infection also led to abscission of noninoculated lower leaves on the plant. Between 10 and $50 \%$ more leaves abscised on inoculated plants than on noninoculated plants. The highest severity of leaf abscission (50\% of total leaves) occurred on 'Amazon' and the least (14\% of total leaves) on 'TMS 30572' (Fig. 5).

\section{DISCUSSION}

Field surveys in three countries of West Africa showed significant variability in incidence and severity of Curvularia stem blight. Planting stock is a major source of inoculum for a stem-infecting pathogen such as C. lunata. In West Africa, it is a common practice for growers to buy initial planting stock and to make subsequent plantings from plants multiplied from the initial stock (25), and to share their planting materials with neighbors. Thus, planting Curvularia-infected stems is an efficient way to spread the disease among fields and may explain the clustered distri- bution of the disease in Ghana and Benin. In Nigeria, however, the disease was widespread rather than in focal groups. This may suggest widespread purchase and/or continued use of infected stems as planting materials.

We examined the entire Benin germplasm collection, and although we were unable to see any visible signs of $C$. lu$n a t a$, accessions were obtained from farmers all around the country. The lack of disease in the collection suggests that clean cuttings were planted and further supports the theory that the use of infected stem cuttings as planting materials was the quickest way to spread the disease. This observation may also suggest that use of clean planting materials can limit the incidence of the disease.

Among the fields surveyed in all three countries, significant variability in disease severity may be related to crop age and/or cultural practices such as weeding, and removal of crop debris. Although these factors were not addressed in the present study, another study in the region (2) reported increased severity of leaf and stem diseases of cassava due to these factors. Differences in severity may also be related to use of germplasm with different levels of resistance. This observation is illustrated in the germplasm collection at Bonsu (Ghana) where 118 accessions were planted in the same field, but only 19 accessions developed symptoms. Resistance to $C$. lunata has been reported in other

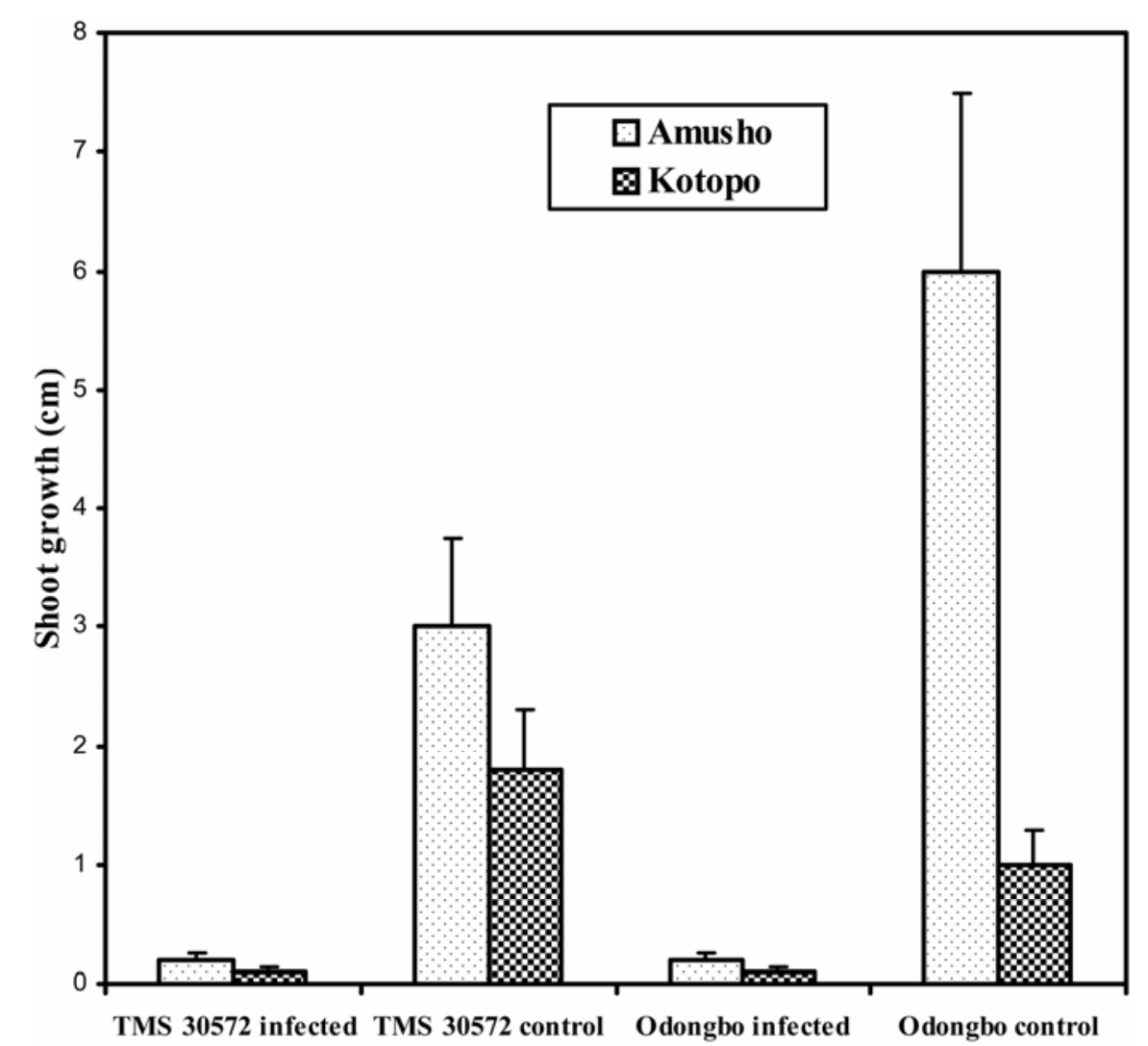

TMS 30572 infected TMS 30572 control Odongbo infected Odongbo control

Fig. 3. Field growth of cassava cultivars TMS 30572 and Odongbo naturally infected with Curvularia

lunata at Amusho and Kotopo in Nigeria. Standard deviation values are shown as error bars.

crops such as sorghum and millets (9), but not in cassava.

Field assessment for leaf damage was complicated by the indistinguishable symptoms between $C$. lunata and Cercospora viscose (blight leaf spot). Thus, leaf infection was only evaluated under controlled conditions in the greenhouse. The results revealed that $C$. lunata infection led to significantly higher leaf abscission than in the noninoculated plants. Cultivars varied significantly in leaf abscission following inoculation with $C$. lunata, suggesting variability in resistance to the disease, a useful trait in crop improvement programs. Under drought, cassava sheds most of the lower leaves (7). However, in this experiment, plants were watered twice per week, which provided sufficient moisture in the soil and hence prevented premature shedding of the leaves. Abscission of noninoculated leaves may suggest that $C$. lunata infection physiologically weakens plants similar to drought stress (3). Physiologically weakened stems sprout poorly and further explain the poor field sprouting observed. In east, central, and southern parts of Africa, cassava leaves are consumed as a vegetable, and loss of leaves negatively impacts the supply of cassava leaves and leads to increased price of the commodity (25). The effect of $C$. lunata infection on cassava root production is yet to be determined.

Stem infections of $C$. lunata negatively affected bud sprouting, especially when 

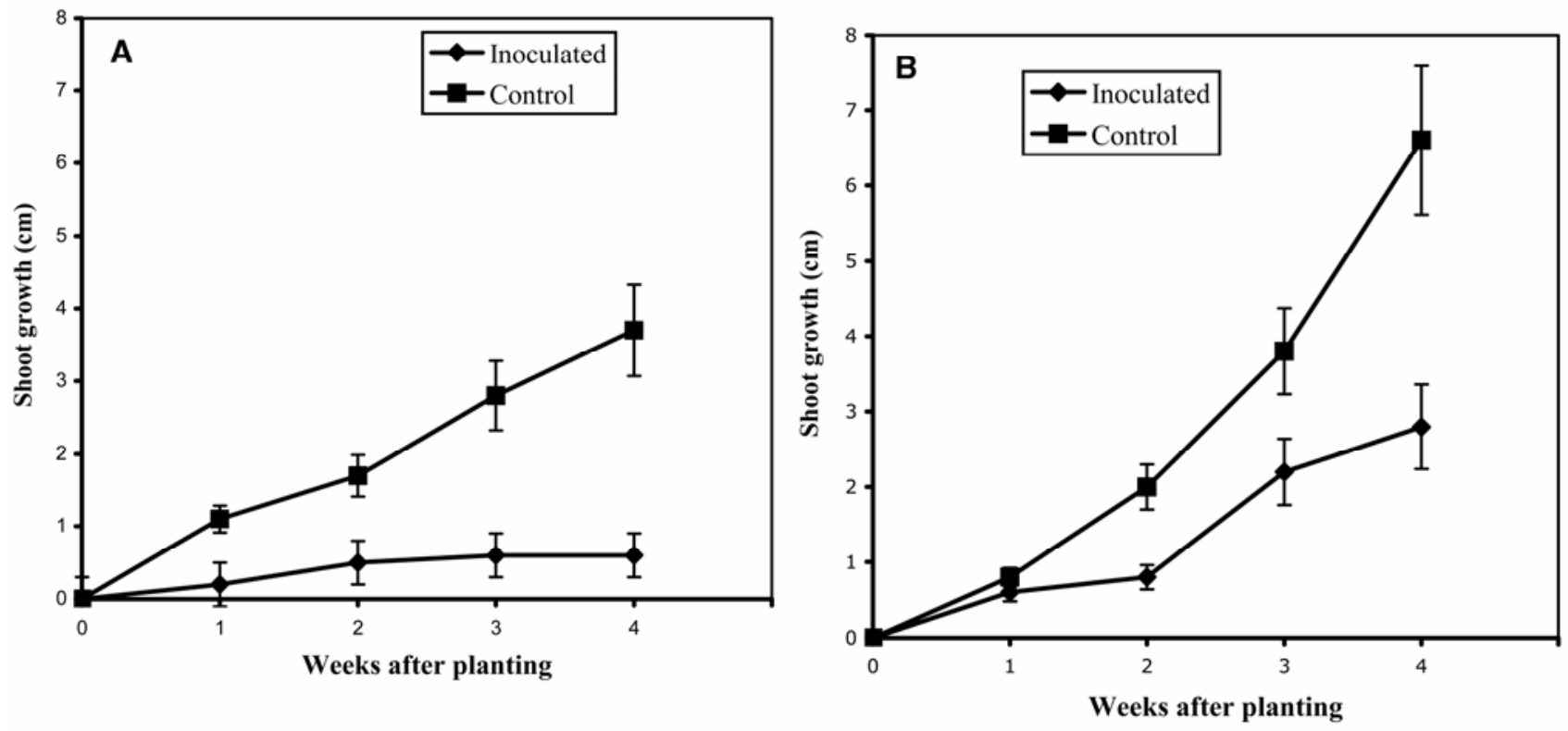

TMS 30572
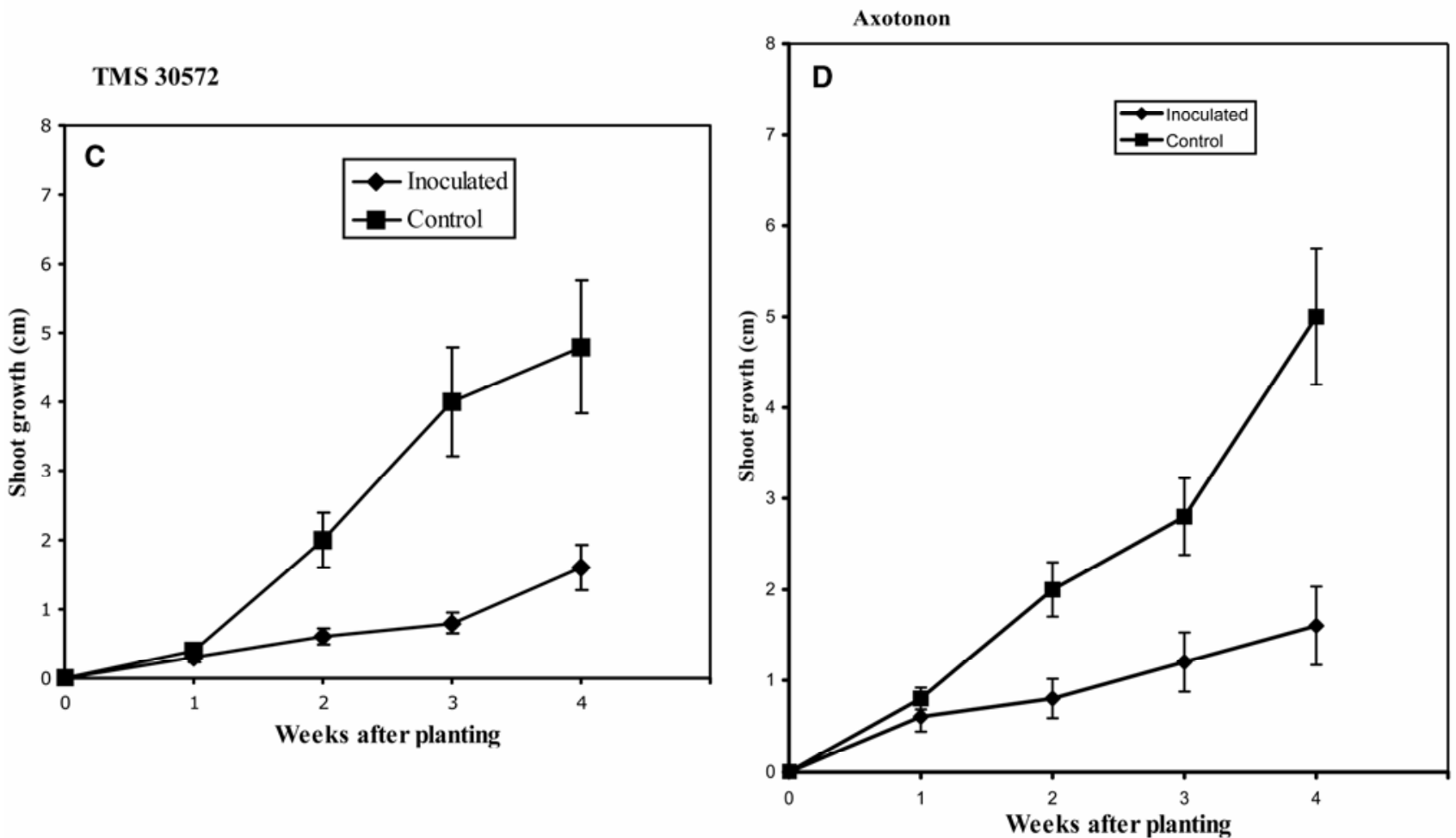

Fig. 4. Growth of four cassava cultivars: A, Amazon, B, Odongbo, C, TMS 30572, and D, Axotonon, artificially inoculated with Curvularia lunata prior to planting in the greenhouse. Standard deviation values are shown as error bars.

buds were completely colonized. In greenhouse studies, colonized buds were killed. However, when buds were partially colonized, growth was significantly reduced but not arrested. Artificially inoculated stems were consistently slower in growth and shorter in stature than the noninoculated stems, suggesting that infection by $C$. lunata weakens the stems. In the field, a similar reduction in shoot growth was observed in comparing growth of infected stems in the two localities. Furthermore, there was a marked variability in overall shoot growth between the two localities, possibly due to variability in soil moisture and/or presence of other pathogens in the soil. These factors were not studied in this experiment.

On stems, $C$. lunata infection was primarily on buds associated with the woody areas and usually failed to colonize green areas of the stem. Although cassava has buds on both the green and woody portions of the stem, the buds on the woody lignified portion of the stem germinate more often than buds on the green portion of the stem (7). By colonizing buds on the woody portion of the stems, Curvularia stem blight lowers the quality of stems and leads to shortages of high-quality planting materials. The association of $C$. lunata with the woody stem portion of the plant may suggest that the fungus is able to digest carbohydrate polymers of the cell walls of cassava tissues. Many fungi, including $C$. lunata $(1,13,17,26,29)$, have the ability to digest cellulose and obtain nutrition from woody stem portions.

C. lunata is also known to be pathogenic on humans-immunocompetent and especially immunocompromised people $(5,28$, 30,33). Humans are infected through the respiratory system or trauma $(12,30)$. Infections have resulted in serious kinds of problems including brain abscess $(5,10,27)$, 


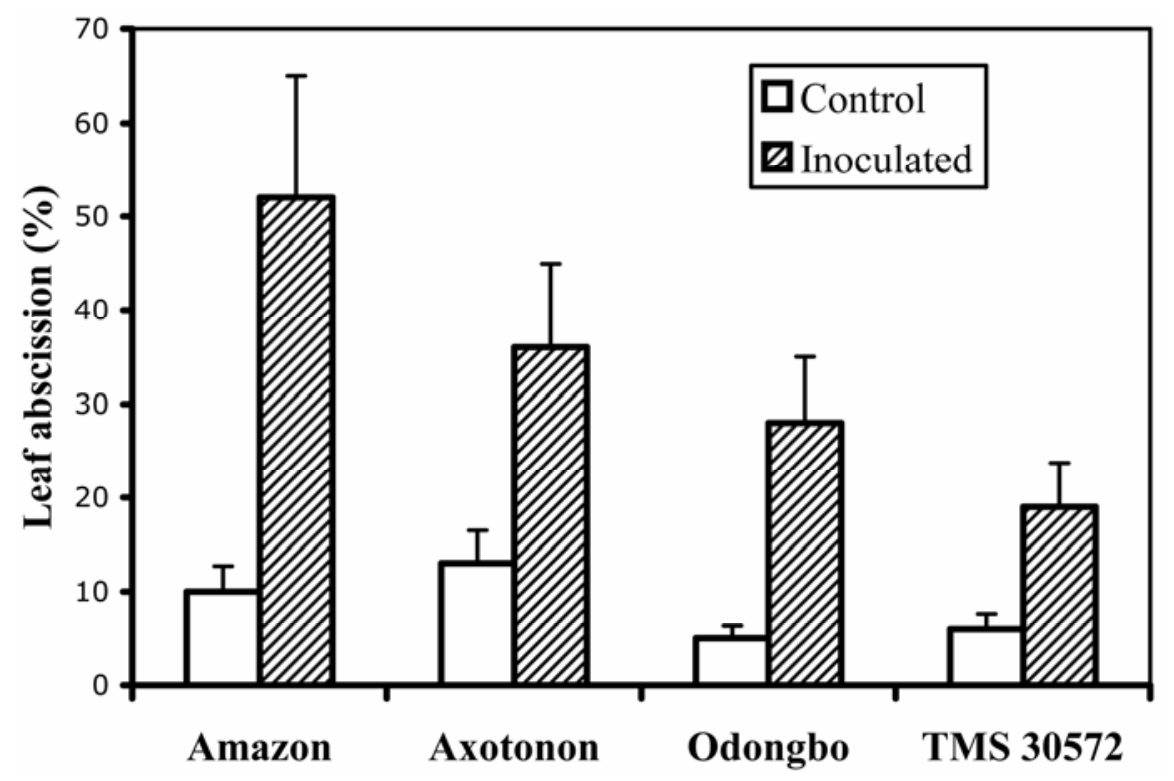

Fig. 5. Influence of Curvularia lunata on leaf retention by four cassava cultivars grown in a greenhouse. Standard deviation values are shown as error bars.

keratitis (32), sinusitis, allergic bronchopulmonary disease, pneumonia, and endocarditis $(30,33)$. Unfortunately, there is paucity of information on isolates of $C$. lunata that infect both humans and plants. In West Africa, conditions that favor the proliferation of $C$. lunata on both plants and animals are easily met. Thus, identifying and characterizing isolates that affect humans and cassava would be vital for generating safe handling guidelines for cassava infected with the fungus.

\section{LITERATURE CITED}

1. Abdel-Hafez, S. I. I. 1982. Cellulosedecomposing fungi of desert soils in Saudi Arabia. Mycopathology 78:73-78.

2. Akano, A., Dixon, A., Mba, C., Barrera, E., and Fregene, M. 2004. Genetic mapping of a dominant gene conferring resistance to cassava mosaic disease. Theor. Appl. Genet. 105:521525 .

3. Alves, A. C., and Setter, T. L. 2000. Response of cassava to water deficit. Crop Sci. 40:131137.

4. Baylet, J., Camain, R., and Segretain, G. 1959. Identification of the agents of maduromycoses of Senegal and Mauritania. Description of a new species. Bull. Soc. Pathol. Exot. Fil. 52:448-477. (In French)

5. Carter, E., and Boudreaux, C. 2004. Fatal cerebral Phaeohyphomycosis due to Curvularia lunata in an immunocompromised patient. J. Clin. Microbiol. 42:5419-5423.

6. Dixit, A., Lewis, W., and Crozier, W. 1993. Comparison of mold capture and mold sensitivity in the United States Gulf Coast. J. Allergy Clin. Immunol. 91:275.

7. El-Sharkawy, M. A. 1993. Drought-tolerant cassava for Africa and Latin America. BioScience 43:441-451.
8. Friedman, A. D., Campos, J. M., Rorke, L. B., Bruce, D. A., and Arbeter, A. M. 1981. Fatal recurrent of Curvularia brain abscess. J. Pediatr. 99:413-415.

9. Frobes, G. A. 1986. Characterization of grain mold resistance in sorghum (Sorghum bicolor L. Moench.). Ph.D. thesis. Texas A\&M University, College Station.

10. Gan, G. G., Jaganathan, V. S., The, A., Goh, K., Ng, K. P., Soo-Hoo, T. S., and Na, S. L. 2003. Disseminated Curvularia lunata infection in a leukemia patient: Case report. J. Infec. Dis. Antimicr. Agents 3:151-154.

11. Hahn, S. K., Isoba, J. C. G., and Ikotun, T. 1989. Resistance breeding in root and tuber crops at the International Institute of Tropical Agriculture (IITA), Ibadan, Nigeria. Crop Prot. 8:147-168.

12. Herráez, P., Rees, C., and Dunstan, R. 2001. Invasive phaeohyphomycosis caused by Curvularia species in a dog. Vet. Pathol. 38:456459.

13. Khalid, M., Yang, W.-J., Kishwar, N., Rajput, Z. I., and Arijo, A. G. 2006. Study of cellulolytic soil fungi and two nova species and new medium. J. Zhejiang Univ. Sci. 7:459-466.

14. Lampert, H. B., Hutto, J. H., Donnelly, W. H., and Shulman, S. T. 1977. Pulmonary and cerebral mycetoma caused by Curvularia pallescens. J. Pediatr. 91:603-605.

15. Lozano, J. C., and Terry, E. R. 1976. Cassava diseases and their control. Pages 156-160 in: Proc. Sympos. Int. Soc. Trop. Root Crops 4th. J. Cook, R. McIntyre, and M. Graham, eds. CIAT, Cali, Colombia.

16. Maghoub, E. S. 1973. Mycetomas caused by Curvularia lunata, Madurella grisea, Aspegillus nidulans, and Nocardia brasiliensis in Sudan. Sabouraudia 11:179-182.

17. Mandels, M., and Reese, E. T. 1965. Inhibition of cellulases. Annu. Rev. Phytopathol. 3:85102.

18. McAleer, R., Kroenert, D. B., Elder, J. L., and
Froudist, J. H. 1981. Allergic bronchopulmonary disease caused by Curvularia lunata and Drechslera hawaiiensis. Thorax 26:338-344.

19. Msikita, W., Bissang, B., James, B. D. Baimey, H., Wilkinson, H. T., Ahounou, M., and Fagbemissi, R. 2005. Prevalence and severity of Nattrassia mangiferae root and stem rot pathogen of cassava in Bénin. Plant Dis. 89:12-16.

20. Msikita, W., James, B., Ahounou, M., Baimey, H., Facho, B. G., and Fagbemissi, R. 1998 The discovery of new diseases of cassava in West Africa. Trop. Agric. (Trinidad) 75:58-63 .

21. Msikita, W., James, B., Ahounou, M., Wilkinson, H. T., and Juba, J. H. 1998. First report of Macrophomina phaseolina causing preharvest cassava root rot in Benin and Nigeria. Plant Dis. 82:1402.

22. Msikita, W., Nelson, P. E., Yaninek, J. S., Ahounou, M., and Fagbemissi, R. 1996. First report of Fusarium moniliforme causing root, stem, and storage rot. Plant Dis. 80:823.

23. Msikita, W., Yaninek, J. S., Ahounou, M Baimey, H., and Fagbemissi, R. 1997. First report of Curvularia lunata associated with stem disease of cassava. Plant Dis. 81:112.

24. Msikita, W., Yaninek, J. S., Ahounou, M., Baimey, H., and Fagbemissi, R. 1997. First report of Nattrassia mangiferae root and stem rot of cassava in West Africa. Plant Dis. 81:1332.

25. Nweke, F. 2004. New challenges in the cassava transformation in Nigeria and Ghana. Environment and Production Technology Division (EPTD) Discussion Paper 118. The International Food Policy Research Institute, Washington DC. Online publication: www.ifpri.org/ divs/eptd/dp/papers/eptdp118.pdf.

26. Ortiz-Bermudez, P., Srebotnik, E., and Hammel, K. E. 2003. Chlorination and cleavage of lignin structures by fungal chloroperoxidases. Appl. Environ. Microbiol. 8:5015-5018.

27. Rinaldi, M. G., Phillips, P., Schwartz, J. G., Winn, R. E., Holt, G. R., Shagets, F. W., Elrod, J., Nishioka, G., and Aufdemorte, T. B. 1987. Human Curvularia infections. Report of five cases and review of the literature. Diagn. Microbiol. Infec. Dis. 6:27-39.

28. Safdar, A. 2003. Curvularia - favorable response to oral itraconazole therapy in two patients with locally invasive pheohyphomycosis. Clin. Microbiol. Infec. 9:1219-1223.

29. Schawartze, F. W. M. R., Engels, J., and Mattheck, C. 2000. Fungal Strategies of Wood Decay in Trees. SpringerVerlag, New York.

30. Tessari, G., Forni, A., Ferretto, R., Solbiati, M., Faggian, G., Mazzucco, A., and Barba, A. 2003. Lethal systemic dissemination from cutaneous infection due to Curvularia lunata in a heart transplant recipient. J. Eur. Acad. Dermatol. Venereol. 17:440-442.

31. Watanabe, T. 1994. Pictorial Atlas of Soil and Seed Fungi: Morphologies of Cultured Fungi and Key to Species. Lewis Publishers, London.

32. Wilhelmus, K. R., and Jones, D. B. 2001. Curvularia keratitis. Trends Am. Ophthal. Soc. 99:111-132.

33. Yau, Y. C., de Nanassy, J., Summerbell, R. C., Matlow, A. G., and Richardson, S. E. 1994. Fungal sternal wound infection due to Curvularia lunata in a neonate with congenital heart disease: Case report and review. Clin. Infec. Dis. 19:735-740. 